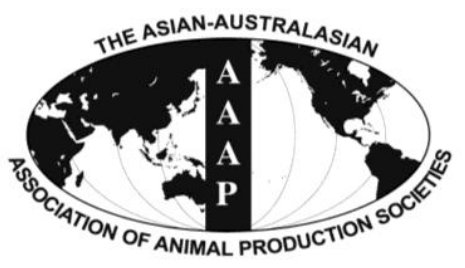

Asian-Aust. J. Anim. Sci.

Vol. 25, No. $7: 1021$ - 1028 July 2012

www.ajas.info

http://dx.doi.org/10.5713/ajas.2012.12033

\title{
Differential Expression of Th1- and Th2- Type Cytokines in Peripheral Blood Mononuclear Cells of Murrah Buffalo (Bubalus Bubalis) on TLR2 Induction by B. Subtilis Peptidoglycan
}

\author{
Syed M. Shah, G. V. P. P. S. Ravi Kumar*, G. S. Brah, Lakshman Santra and Hitesh Pawar \\ Post-Graduate Institute of Veterinary Education and Research, \\ Guru Angad Dev Veterinary and Animal Sciences University, Ludhiana, Punjab-141004, India
}

\begin{abstract}
Peripheral blood mononuclear cells (PBMCs) discriminate microbial pathogens and induce T-cell responses of appropriate effector phenotype accordingly. Toll-like receptors (TLRs), in part, mediate this microbial recognition and differentiation while the development of T-cell effector functions critically depends on the release of Th1- or Th2- type cytokines. In the present study, buffalo PBMCs were stimulated under in vitro culture conditions by Bacillus subtilis cell wall petidoglycan, a TLR2 ligand, in a doseand time- dependent manner. The expression of TLR2 as well as the subsequent differential induction of the Th1 and Th2 type cytokines was measured. Stimulation was analyzed across five doses of peptidoglycan (10 $\mu \mathrm{g} / \mathrm{ml}, 20 \mu \mathrm{g} / \mathrm{ml}, 30 \mu \mathrm{g} / \mathrm{ml}, 40 \mu \mathrm{g} / \mathrm{ml}$ and $50 \mu \mathrm{g} / \mathrm{ml})$ for $3 \mathrm{~h}, 12 \mathrm{~h}, 24 \mathrm{~h}$ and $36 \mathrm{~h}$ incubation periods. We observed the induction of TLR2 expression in a dose- and time-dependent manner and the peptidoglycan induced tolerance beyond $30 \mu \mathrm{g} / \mathrm{ml}$ dose at all incubation periods. The correlation between peptidoglycan stimulation and TLR2 induction was found positive at all doses and for all incubation periods. Increased production of all the cytokines was observed at low doses for $3 \mathrm{~h}$ incubation, but the expression of IL-4 was relatively higher than IL-12 at the higher antigen doses, indicating tailoring towards Th2 response. At $12 \mathrm{~h}$ incubation, there was a pronounced decrease in IL-4 and IL-10 expression relative to IL-12 in a dose- dependent manner, indicating skewing to Th1 polarization. The expression of IL-12 was highest for all doses across all the incubation intervals at $24 \mathrm{~h}$ incubation, indicating Th1 polarization. The relative expression of TNF- $\alpha$ and IFN- $\gamma$ was also higher while that of IL-4 and IL-10 showed a decrease. For $36 \mathrm{~h}$ incubation, at low doses, relative increase in the expression of IL-4 and IL-10 was observed which decreased at higher doses, as did the expression of all other cytokines. The exhaustion of cytokine production at 36 $\mathrm{h}$ indicated that PBMCs became refractory to further stimulation. It can be concluded from this study that the cytokine response to sPGN initially was of Th2 type which skews, more pronouncedly, to Th1 type with time till the cells become refractory to further stimulation. (Key Words: Differential Cytokine Induction, Buffalo PBMCs, Th1 and Th2 Type Cytokines, Bacillus subtilis Peptidoglycan)
\end{abstract}

\section{INTRODUCTION}

The innate immune response in vertebrates, mediated by neutrophils, macrophages and dendritic cells, is the first line of defense against invading microorganisms. These cells can discriminate between pathogens and self by utilizing signals from Toll-like receptors (TLRs). TLRs enable the innate immune system to recognize specific pathogen associated molecular patterns (PAMPs) as well as induce specific cytokine profiles bringing a certain degree of

\footnotetext{
* Corresponding Author: G. V. P. P. S. Ravi Kumar. Tel: +91 9458687850, Fax: +915812302179, E-mail: gandham1971@ gmail.com

Submitted Jan. 13, 2012; Accepted Mar. 4, 2012; Revised Mar. 29, 2012
}

specificity to the innate immune system, thereby influencing the nature of the adaptive immune response. The mammalian TLR multi-gene family comprises of at least 11 members, of which TLRs 1-9 are conserved between humans and mouse. These are Type1 transmembrane proteins and have been grouped into the same gene family due to their sequence similarity (Gay and Keith, 1991). The complete set of TLRs can detect a broad variety of microorganisms, viz; bacteria, viruses, fungi and even some protozoa. Among the known TLRs, TLR2 is primarily implicated in recognition of Gram-positive bacterial cell wall components, especially peptidoglycan (PGN). Grampositive bacterial PGN activates cells primarily through TLR2 which results in the activation of the transcription 
factor NF- $\mathrm{KB}$, a ubiquitous factor, that regulates the transcription of various cytokine genes involved in immune responses (Wang et al., 2001). These cytokines provide a polarizing signal, which constitutes one of the three distinct signals required for the activation of $\mathrm{T}$ cells by antigen presenting cells. Among the cytokines, IL-12 production tailors a Th1-type response, whereas IL-4 and IL-10 activate mainly Th2-type responses (Medzhitov, 2001). Depending upon the type of infectious agent, TLRs cause skewing towards the production of either pro-inflammatory Th1 type cytokines (IL-12, IFN- $\gamma$ and TNF- $\alpha$ ) or Th2 type cytokines, viz; IL-4 and IL-10, which are associated with the promotion of $\operatorname{IgE}$ and are anti-inflammatory in response (Wang et al., 2000). Recent research on vaccine development has focused on adjuvant improvement which can promote stable induction of Th1 immunity with minimal side effects by investigating ways to redirect Th2 responses in favour of Th1 responses. TLRs have been suggested to function as the desirable vaccine adjuvants (Hirschfeld et al., 2001). TLR2 is the most promiscuous of all the TLRs and has received an extra attention due to contrasting opinions about its ligand specificity and thereby differential cytokine induction (Travassos et al., 2004; Dziarski and Gupta, 2005). Furthermore, the health and infectious diseases of buffalo are currently being managed much like those of cattle which however, especially of young calves, are different. To successfully adapt cattlebased strategies of health management to buffalo, it is necessary to understand their immune system as well as the variables involved in differential disease susceptibility and resistance. Such studies will not only contribute to improvement in the management of buffalo, but will also provide an insight into the mechanisms accounting for the differences in disease resistance (Thanislass et al., 2009). In this context, the present study was conducted to study the cytokine response by buffalo peripheral blood mononuclear cells, under culture conditions, to B. subtilis cell wall peptidoglycan in a dose- and time- dependent manner.

\section{MATERIALS AND METHODS}

\section{PBMC isolation, recovery and viability}

Blood samples were collected from six healthy and immunocompetent Murrah buffalo heifers, aged two and a half years, maintained at Dairy farm, GADVASU, Ludhiana. Fifteen $\mathrm{ml}$ of blood per heifer was collected in 0.5 M EDTA aseptically and stored at $4{ }^{\circ} \mathrm{C}$ till further use. The blood samples were processed within two hours for peripheral blood mononuclear cell (PBMCs) isolation by density gradient centrifugation, using Histopaque 1077 (Sigma, USA). Briefly, five $\mathrm{ml}$ of the collected blood sample was diluted in equal volume of phosphate buffered saline (PBS, $\mathrm{pH}$ 7.4) and layered over onto the equal volume of
Histopaque 1077 (Sigma, USA), followed by centrifugation at $400 \mathrm{~g}$ for $25 \mathrm{~min}$, break off, at room temperature. The buffy layer, containing mononuclear cells, was separated, washed twice with RPMI-1640 media, supplemented with 10mM HEPES, $50 \mu \mathrm{g} / \mathrm{ml}$ Gentamicin, $100 \mathrm{IU} / \mathrm{ml}$ of Penicillin, $100 \mu \mathrm{g} / \mathrm{ml}$ Streptomycin and $0.25 \mu \mathrm{g} / \mathrm{ml}$ Amphotericin, and sedimented to a pellet at $200 \mathrm{~g}$ for 10 min. The recovery and viability of the isolated PBMCs was determined by haemocytometer counting, using trypan blue dye exclusion method. $10 \mu \mathrm{l}$ of the cell suspension was mixed with $10 \mu$ of $0.4 \%$ trypan blue and incubated for 3 to $5 \mathrm{~min}$ at room temperature. $10 \mu \mathrm{l}$ of this mixture was injected beneath the cover slip on a haemacytometer. The unstained (viable) and stained (dead) cells were counted from the central large squares of haemacytometer. The total number of viable cells counted on an average was $2.4 \times 10^{6} / \mathrm{ml}$, accounting for $91 \%$ viability.

\section{PBMC culture and stimulation}

$500 \mu \mathrm{l}$ of the isolated PBMC suspension per $\mathrm{ml}$ of the culture volume $\left(2.4 \times 10^{6}\right.$ viable cells $\left./ \mathrm{ml}\right)$, was cultured in RPMI-1640 medium supplemented with HEPES Buffer (10 $\mathrm{mM}$ ), L-glutamine (2 $\mathrm{mM})$, Gentamicin $(50 \mu \mathrm{g} / \mathrm{ml})$, Pencillin (100 IU/ml), Streptomycin $(100 \mu \mathrm{g} / \mathrm{ml})$ and Amphotericin B $(0.25 \mu \mathrm{g} / \mathrm{ml})$ and stimulated with peptidoglycan (sPGN) of Bacillus subtilis cell wall origin (Sigma Life sciences, USA) in a dose- and time- dependent manner. The working concentration of the soluble petidoglycan ( $\mathrm{sPGN}$ ), prepared in sterile tissue culture grade endotoxin free water, was $1 \mu \mathrm{g} / \mu \mathrm{l}$. The cultures in 6well tissue culture plates were stimulated with 10, 20, 30, 40 and $50 \mu \mathrm{g} / \mathrm{ml}$ final dose of sPGN. A non-stimulated culture plate acted as the control. The cultures were incubated at $37^{\circ} \mathrm{C}$ and $5 \% \mathrm{CO}_{2}$ under humidified conditions for $3 \mathrm{~h}, 12 \mathrm{~h}, 24 \mathrm{~h}$ and $36 \mathrm{~h}$ time periods with media changes every $12 \mathrm{~h}$. All the culture wells were microscopically examined at appropriate intervals to rule out bacterial and fungal contamination.

\section{Extraction of total RNA}

After the respective incubation periods, the total RNA from the cultured PBMCs was extracted using Tri reagent (MRC, Inc.) as per the manufacturer's protocol with slight modifications. Briefly, $1 \mathrm{ml}$ Tri reagent was added to the pellet, lysed by repetitive pipetting, followed by addition of $1 \mathrm{ml}$ chloroform. After vortexing the tubes were kept at room temperature for $15 \mathrm{~min}$, then centrifuged at 10,000 $\mathrm{rpm}$ for $10 \mathrm{~min}$ at $4^{\circ} \mathrm{C}$. $600 \mu \mathrm{l}$ of the aqueous phase, containing total RNA, was aspirated out and equal volume of isopropanol added, followed by incubation at room temperature for $1 \mathrm{~h}$. RNA pellet was obtained by centrifugation at $10,000 \mathrm{rpm}$ for $10 \mathrm{~min}$ at $4^{\circ} \mathrm{C}$, washed 
with $70 \%$ ethanol, air-dried and finally dissolved in $0.1 \%$ DEPC treated water and incubated at $56^{\circ} \mathrm{C}$ for $15 \mathrm{~min}$. The extracted RNA was quantified and checked for purity in Nano drop. Its integrity was further checked by Experion automated electrophoresis system which showed distinct peaks for $18 \mathrm{~S}$ and $28 \mathrm{~S}$ ribosomal RNA (rRNA) indicating that the RNA was pure and without any shearing or fragmentation.

\section{Reverse transcription-PCR}

The samples with 260/280 greater than 1.9 were used for cDNA synthesis employing QuantiTect reverse Transcription Kit (Qiagen). First the genomic DNA elimination reaction was prepared on ice by adding $2 \mu \mathrm{l}$ of gDNA Wipeout Buffer (7×) to $1 \mu$ l of template RNA $(1,000$ ng) in $11 \mu \mathrm{l}$ of RNase-free water. The reaction mixture was incubated for $2 \mathrm{~min}$ at $42^{\circ} \mathrm{C}$, then immediately placed on ice. This template RNA reaction $(14 \mu \mathrm{l})$ was added to the preformed reverse transcription master mix which was prepared on ice by addition of $1 \mu \mathrm{l}$ of Quantiscript Reverse Transcriptase, $4 \mu \mathrm{l}$ of Quantiscript RT Buffer $(5 \times)$ and $1 \mu \mathrm{l}$ of RT Primer Mix. The tubes were incubated for $25 \mathrm{~min}$ at $42^{\circ} \mathrm{C}$ in water bath, followed by inactivation at $95^{\circ} \mathrm{C}$ for 3 min. The amplification of $218 \mathrm{bp}$ GAPDH gene fragment from the cDNA indicated the presence of cDNA.

\section{Real-time PCR}

Quantitative real-time PCR was performed using 7500
RT-PCR instrument (ABS) to study the relative gene expression of TLR2, IL-12, IFN- $\gamma$, TNF- $\alpha$, IL-4 and IL-10, using gene specific primer- probe combinations (Sigma Aldrich, USA), by Taqman chemistry. The software package, Primer Express version 3.0, was used to identify appropriate TaqMan primer- probe sets for the respective genes selected (Table 1). The primer-probe set for TLR2 was obtained from its EST, sequenced earlier in the lab (Shah et al., 2010); (Genbank accession No. GU441859.1). The optimized qRT-PCR reaction contained $100 \mathrm{ng}$ of cDNA, $900 \mathrm{nM}$ of each of the primer and $200 \mathrm{nM}$ of the probe in a final volume of $20 \mu \mathrm{l}$. The reactions were run in triplicate using GAPDH as an endogenous control. The thermal cycling parameters, $50^{\circ} \mathrm{C}$ for $2 \mathrm{~min}$ for AmpErase UNG activation, $95^{\circ} \mathrm{C}$ for $10 \mathrm{~min}$ for AmpliTaq Gold DNA Pol. activation and 40 cycles of each $95^{\circ} \mathrm{C}$ for $15 \mathrm{~s}$ for denaturation/melting and $60^{\circ} \mathrm{C}$ for $1 \mathrm{~min}$ for annealing and extension, yielded optimum amplification. For the test genes and endogenous control standards 10-fold serial dilutions were run in the study to estimate the efficiency of PCR and the percentage efficiency ranged between 90 to $100 \%$. The relative expression of each sample was calculated using the $2^{-\Delta \Delta \mathrm{CT}}$ method (Schmittgen and Livak 2008). Results were analyzed and shown as fold change ( $\log _{10}$ relative quantification) relative to the control group.

\section{Statistical analysis}

Analysis of variance with Dunett's test was used to

Table 1. Primers and probes for qRT-PCR

\begin{tabular}{|c|c|c|c|c|}
\hline Gene & & Sequence (5' to 3') & Len. & $\operatorname{Tm}\left({ }^{\circ} \mathrm{C}\right)$ \\
\hline \multirow{3}{*}{$\begin{array}{l}\text { TLR2 } \\
\text { (GU44I859.1) }\end{array}$} & Forward & CTGGCCCTTCCTTCAAACC & 19 & 65.7 \\
\hline & Reverse & TCCCGTTTTTTCTAGTGATTTCAAA & 25 & 65.2 \\
\hline & Probe & [6FAM]TGGTTTTAAGGCAGAATC[BHQ1] & 18 & 55.0 \\
\hline \multirow{3}{*}{$\begin{array}{l}\text { IL-4 } \\
\qquad(A Y 293620)\end{array}$} & Forward & GCCACACGTGCTTGAACAAA & 20 & 67.2 \\
\hline & Reverse & TGCCAAGCTGTTGAGATTCCT & 21 & 66.0 \\
\hline & Probe & [6FAM]CCTGGGCGGACTC[BHQ1] & 13 & 53.0 \\
\hline \multirow{3}{*}{$\begin{array}{l}\text { IL-10 } \\
\qquad(A B 246351)\end{array}$} & Forward & TGCCACAGGCTGAGAACCA & 19 & 68.3 \\
\hline & Reverse & TCTCCCCCAGCGAGTTCA & 18 & 67.2 \\
\hline & Probe & [6FAM]CCTGACATCAAGGAGCA[BHQ1] & 17 & 58.0 \\
\hline \multirow{3}{*}{$\begin{array}{l}\text { IL-12 } \\
\text { (EF424254) }\end{array}$} & Forward & AAAAGCAGCAGAGGCTCCT & 19 & 58.0 \\
\hline & Reverse & GTCCACGCTGACCTTCTCT & 19 & 56.0 \\
\hline & Probe & [6FAM]CTGCTCCGCACGTCAG[BHQ1] & 16 & 55.0 \\
\hline \multirow{3}{*}{$\begin{array}{l}\text { IFN- } \gamma \\
(\text { EF424252) }\end{array}$} & Forward & TGAATGACCTGTCGCCAAAAT & 21 & 66.4 \\
\hline & Reverse & GGCCTCGAAAGAGATTCTGACTT & 23 & 65.7 \\
\hline & Probe & [6FAM]ACCTCAGAAAGCGGAAG[BHQ1] & 17 & 58.0 \\
\hline \multirow{3}{*}{$\begin{array}{l}\text { TNF- } \alpha \\
(\text { EF424254) }\end{array}$} & Forward & ACTCATATGCCAATGCCCTCATG & 23 & 59.0 \\
\hline & Reverse & GCAGGCACCACCAGCT & 16 & 57.0 \\
\hline & Probe & [6FAM]ACGGCGTGAAGCTAG[BHQ1] & 15 & 57.0 \\
\hline \multirow{3}{*}{$\begin{array}{l}\text { GAPDH } \\
\text { (DQ882684) }\end{array}$} & Forward & GAAGGTGAAGGTCGGAGTC & 19 & 57.0 \\
\hline & Reverse & GAAGATGGTGATGGGATTTC & 20 & 58.0 \\
\hline & Probe & [6FAM]CAAGCTTCCCGTTCTCAGCC[BHQ1] & 20 & 55.0 \\
\hline
\end{tabular}


compare the different groups with the control (JMP 8.0). The data are mean triplicate of the three experiments. Differences were considered significant at $\mathrm{p} \leq 0.05$.

\section{RESULTS}

After $3 \mathrm{~h}$ incubation, the relative expression of TLR2 gene was found to increase in dose- dependent manner. Its expression was highest at $30 \mu \mathrm{g} / \mathrm{ml}$ dose of sPGN. The relative expression of IL-4 followed a general increasing trend as the dose of sPGN increased, being highest at 30 $\mu \mathrm{g} / \mathrm{ml}$. It was greater than all other cytokines at all doses of sPGN. The relative expression of IL-10 was highest at 20 $\mu \mathrm{g} / \mathrm{ml}$ sPGN dose, after which it decreased. IL-12 expression was greater than that of non- stimulated control, remained stable upto $30 \mu \mathrm{g} / \mathrm{ml} \mathrm{sPGN}$ concentration beyond which it decreased more pronouncedly than IL-4. The relative expression of IFN- $\gamma$ was highest at $20 \mu \mathrm{g} / \mathrm{ml}$ sPGN dose after which it was lesser than that of the nonstimulated control. TNF- $\alpha$ showed increased relative expression at all doses of the antigen with respect to the control, being highest at $20 \mu \mathrm{g} / \mathrm{ml}$ dose and least at 50 $\mu \mathrm{g} / \mathrm{ml}$ dose of the antigen. At $50 \mu \mathrm{g} / \mathrm{ml}$ dose of sPGN, i.e. at higher concentrations, the relative expression of IL-4 was greater than other cytokines thereby tailoring a Th2 type cytokine response (Figure 1). The correlation between the sPGN dose and TLR2 expression was positive (0.563; $\mathrm{p}<0.05)$. The correlations were also positive between: induction of TLR2 and IL-4 (0.923; $<<0.05)$, TLR2 and IL$10(0.752 ; \mathrm{p}<0.05)$ and TLR2 and IL-12 (0.646; $<<0.05)$. At $12 \mathrm{~h}$ incubation, the relative expression of TLR2 gene increased with respect to non- stimulated control in all the treatment groups. The kinetics of increase was concentration dependent being highest at $30 \mu \mathrm{g} / \mathrm{ml}$ dose of sPGN. The relative expression of IL-4 and IL-10 was down regulated after $20 \mu \mathrm{g} / \mathrm{ml}$ sPGN dose. IL-12 showed dosedependent increase in its expression, highest at $50 \mu \mathrm{g} / \mathrm{ml}$. The expression of IFN- $\gamma$ and TNF- $\alpha$ was highest at 20 $\mu \mathrm{g} / \mathrm{ml}$ dose, after which the later showed a more drastic decrease than the former. A general trend followed in which the expression of Th2 type cytokines decreased more pronouncedly than Th1 type cytokines (Figure 2). Thus, at
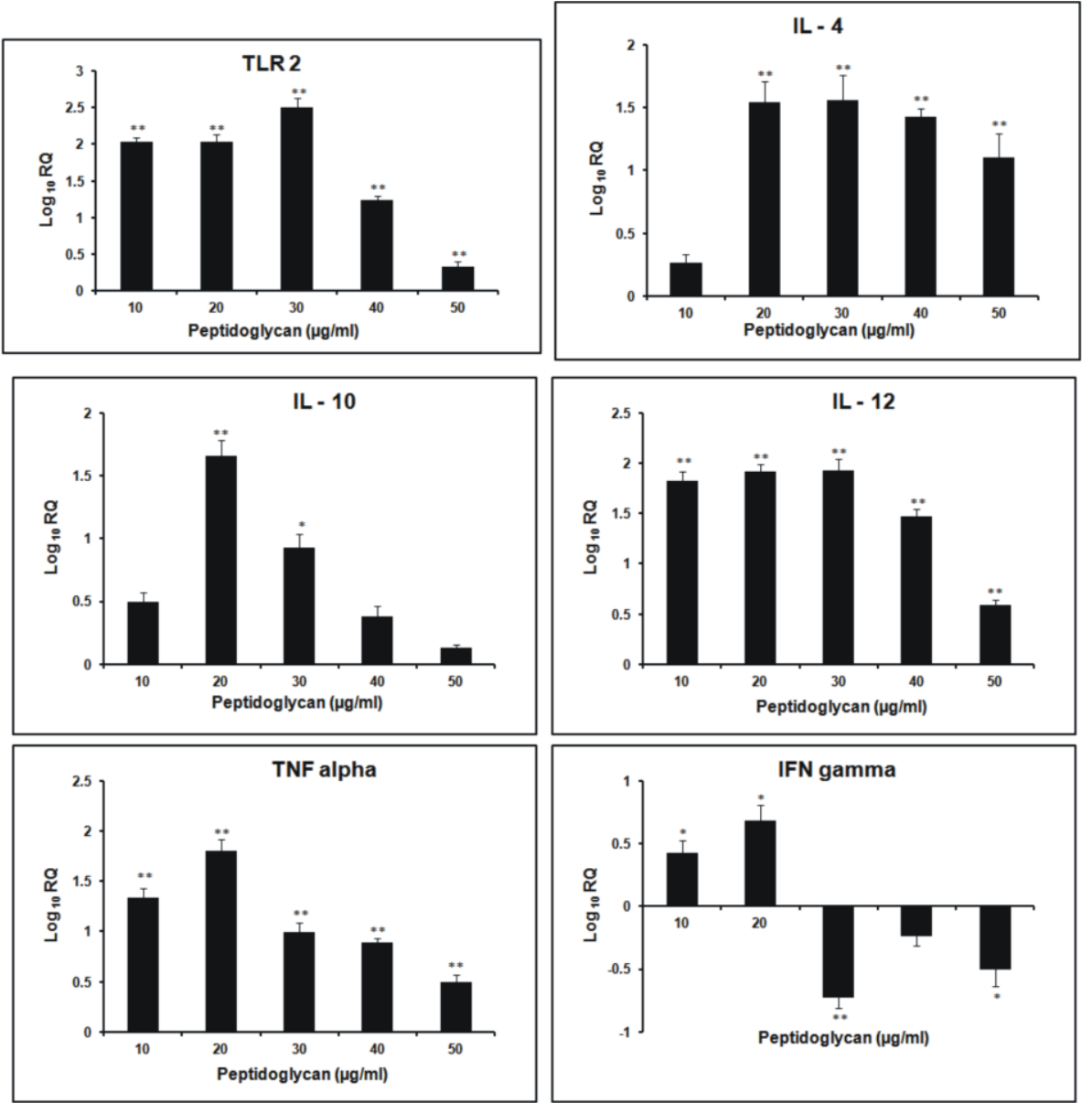

Figure 1. qPCR of TLR2, IL-12, TNF- $\alpha$, IFN- $\gamma$, IL-10 and IL-4 genes after stimulation with $B$. subtilis peptidoglycan for 3 h. Results shown as fold change $\left(\log _{10}\right.$ relative quantification (RQ)) relative to the control group. The data are the means and SEM. * p<0.05 and $* * \mathrm{p}<0.01$. 

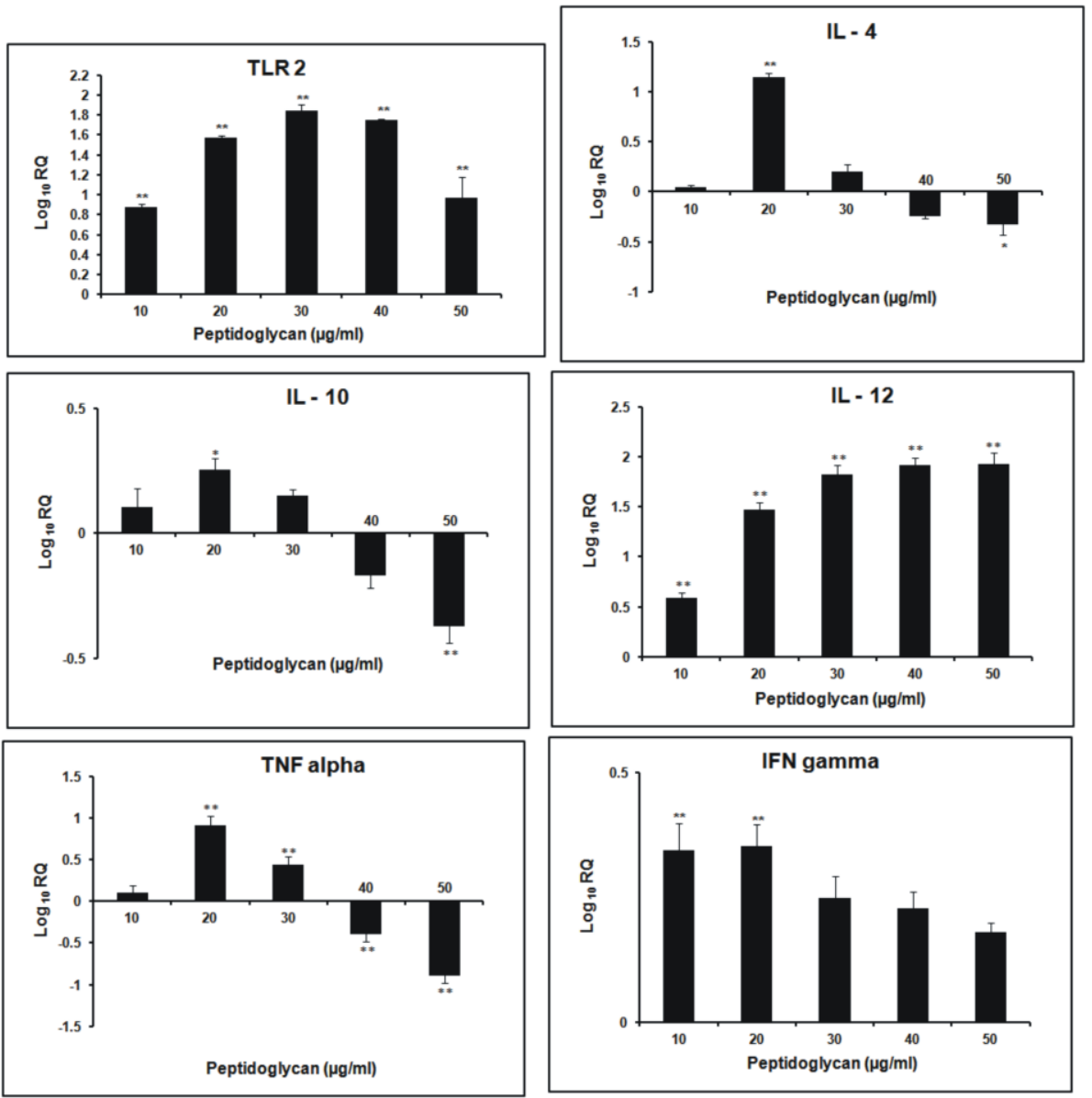

Figure 2. qPCR of TLR2, IL-12, TNF- $\alpha$, IFN- $\gamma$, IL-10 and IL-4 genes after stimulation with $B$. subtilis peptidoglycan for 12 h. Results shown as fold change $\left(\log _{10}\right.$ relative quantification $\left.(\mathrm{RQ})\right)$ relative to the control group. The data are the means and $\mathrm{SEM}$. ${ }^{*} \mathrm{p}<0.05$ and $* * \mathrm{p}<0.01$.

higher concentrations of antigen and for longer incubation periods, sPGN favoured a Th1 type bias. The correlation was positive between sPGN dose and TLR2 expression $(0.76 ; \mathrm{p}<0.05)$ and between TLR2 and IL-12 expression (0.537; $\mathrm{p}<0.05)$, while TLR2 and IL-4 expressions were negatively correlated $(-0.068 ; \mathrm{p}<0.05)$. The relative gene expression study of TLR2 for $24 \mathrm{~h}$ incubation period showed an increasing trend till $40 \mu \mathrm{g} / \mathrm{ml}$ dose of sPGN. IL-4 and IL-10 showed greater expression than that of the control at $10 \mu \mathrm{g} / \mathrm{ml}$ dose of sPGN only. The relative expression of IL-12 was positive throughout, increasing in a dose-dependent manner till $40 \mu \mathrm{g} / \mathrm{ml}$. The relative expression of IFN- $\gamma$ and TNF- $\alpha$ also showed the dosedependent increase (Figure 3). The relative expression of IL-12 with respect to the control was greater than that of all other cytokines at all sPGN doses across all incubation intervals, thereby tailoring the response towards Th1 type. Its expression pattern was almost similar to that of TLR2 showing that TLR2 signaling cascades have a direct impact on governing the cytokine profile in response to an antigen. The correlations, between sPGN dose and TLR2 (0.873; $\mathrm{p}<0.05)$ and TLR2 and IL-12 (0.801; $\mathrm{p}<0.05)$ were positive, while TLR2 and IL-4 were negatively correlated (-0.0687; $\mathrm{p}<0.05)$. The quantification of mRNA for $36 \mathrm{~h}$ incubation periods revealed that the expression of TLR2 increased proportionately till $20 \mu \mathrm{g} / \mathrm{ml}$ dose of sPGN and decreased thereon. The expression of IL-4 and IL-10 was greater than control at 10 and $20 \mu \mathrm{g} / \mathrm{ml}$ dose of sPGN while IL-12 showed decreased expression across all antigen doses. The relative expression of IFN- $\gamma$ and TNF- $\alpha$ was highest at 10 $\mu \mathrm{g} / \mathrm{ml}$ dose of the antigen beyond which it was lower than that of the control (Figure 4). The correlation was positive between sPGN dose and TLR2 expression $(0.0676 ; \mathrm{p}<0.05)$ and between TLR2 and IL-4 (0.0146; $<<0.05)$; and negative between TLR2 and IL-12 (-0.0454; $\mathrm{p}<0.05)$. The overall cytokine induction profile, taken as the net average, for an incubation period is depicted in Table 2.

\section{DISCUSSION}

The relative increase in TLR2 expression at all doses for all incubation periods is due to induction caused by sPGN stimulation which is the ligand for TLR2 that activates its transcription (Akira and Sato, 2003). Its expression is 

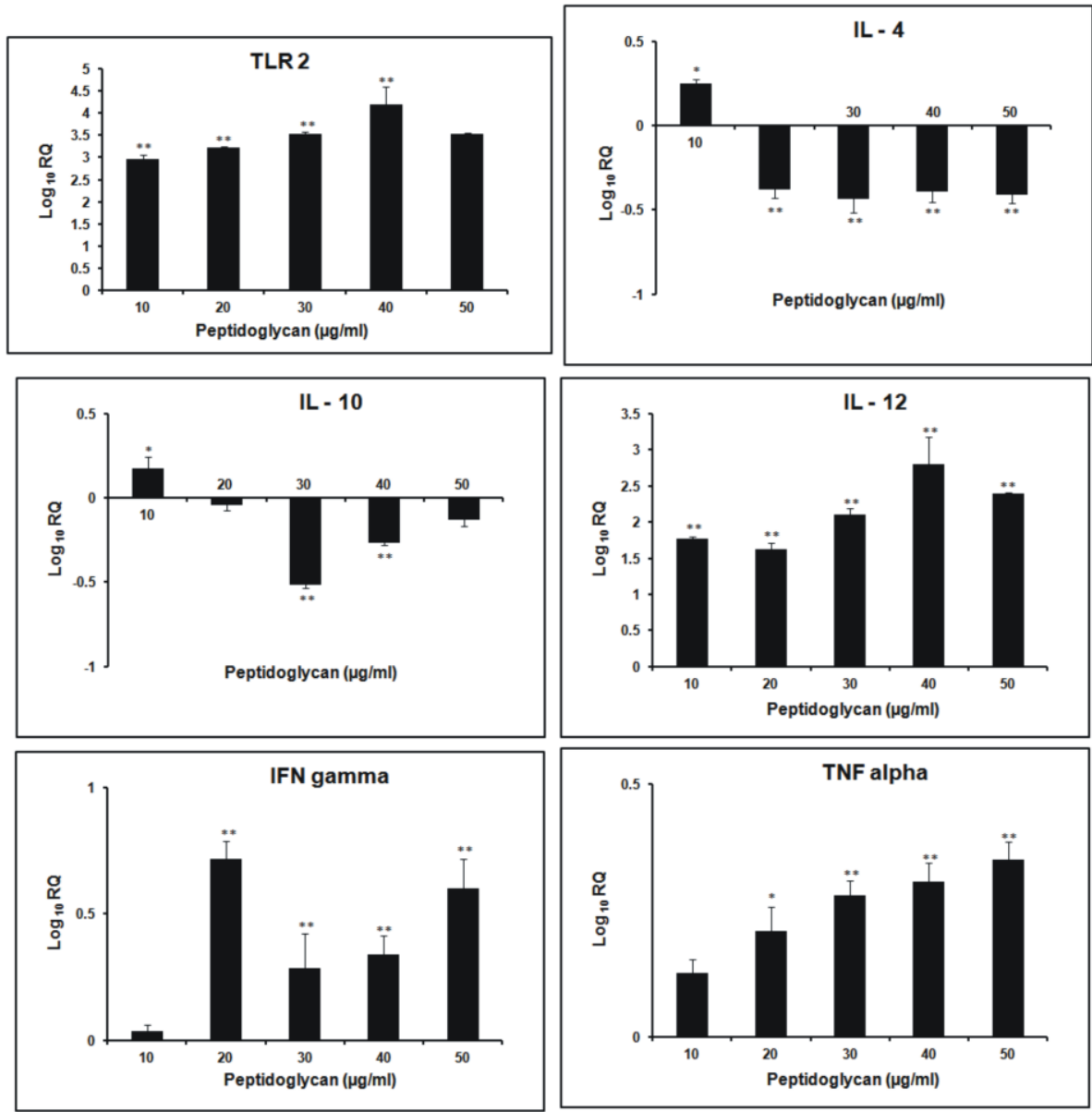

Figure 3. qPCR of TLR2, IL-12, TNF- $\alpha$, IFN- $\gamma$, IL-10 and IL-4 genes after stimulation with $B$. subtilis peptidoglycan for 24 h. Results shown as fold change $\left(\log _{10}\right.$ relative quantification $\left.(\mathrm{RQ})\right)$ relative to the control group. The data are the means and SEM. * p<0.05 and $* * \mathrm{p}<0.01$.

further up regulated in vitro by autocrine cytokines, IL-10 and TNF- $\alpha$ which are produced by the stimulated PBMCs (Zarember and Godowski, 2002). The decrease in expression of TLR2 beyond $30 \mu \mathrm{g} / \mathrm{ml}$ dose of sPGN may be due to sPGN induced tolerance (Nakayama et al., 2004) and concomitant decrease in its up regulating cytokines, as observed in our study.

At $3 \mathrm{~h}$ incubation period the initial increased production of both Th1 and Th2 type cytokines at lower sPGN doses may be due to a very high proportion of $\mathrm{CD}^{-} \mathrm{CD}^{-} \mathrm{T}$ cells in peripheral blood lymphocytes in bovines (15 to $30 \%$ ) which represent a $\mathrm{Th} 0$ subpopulation that secrete a mixture of cytokines, especially IL-12 and IL-4, representatives of both Th1 and Th2 subtypes (Tizard, 1996). It has been reported earlier that if both IL-12 and IL-4 are present at the time of $\mathrm{T}$ cell activation, the effect of the IL-4 dominates and the $\mathrm{T}$ lymphocytes polarize to become Th2 effectors (Perez et al., 1995). Further the ligation of the IL-4 receptor on Th0 cells triggers activation of signal transducer and activator of transcription 6 (STAT6) which suppresses Th1 polarization and leads to Th2 polarization (Spellberg and Edwards, 2001). Thus the Th2 polarization, as observed in our study, is primarily due to more relative expression of IL-4 than IL-10 which directly enhances the development of Th2 cells from naïve T cells (Abbas et al., 1996). IL-10 further inhibits the production of IL-12, IFN- $\gamma$ and TNF- $\alpha$ thereby explaining the decrease in their relative expressions (D'Andrea et al., 1993). The findings reveal that the activation of TLR2 by sPGN at smaller incubation intervals induces skewing towards Th2 development as observed by Hirschfeld et al. (2001) in their studies. Thus, in vitro, stimulation of PBMCs with higher doses of sPGN for shorter periods of time $(3 \mathrm{~h})$ causes differentiation of naive $\mathrm{T}$ cells preferentially into $\mathrm{Th} 2$ sub group. At the longer incubation time of $12 \mathrm{~h}$, with increasing sPGN dose, the decrease in the expression of IL-4 was more pronounced than IL-12 overcoming its dominating effect as observed at shorter incubation $(3 \mathrm{~h})$. The expression of IL-12 was more profound than IL-4, inferring that at higher concentrations of antigen and for greater periods of exposure, naïve $\mathrm{T}$ cells showed Th1 polarization. IL-12 acts synergistically with IFN- $\gamma$ and down regulates Th2 type cellular proliferation and activation, thereby explaining the reason for lower relative expression of Th2 type cytokines (Mosmann and 

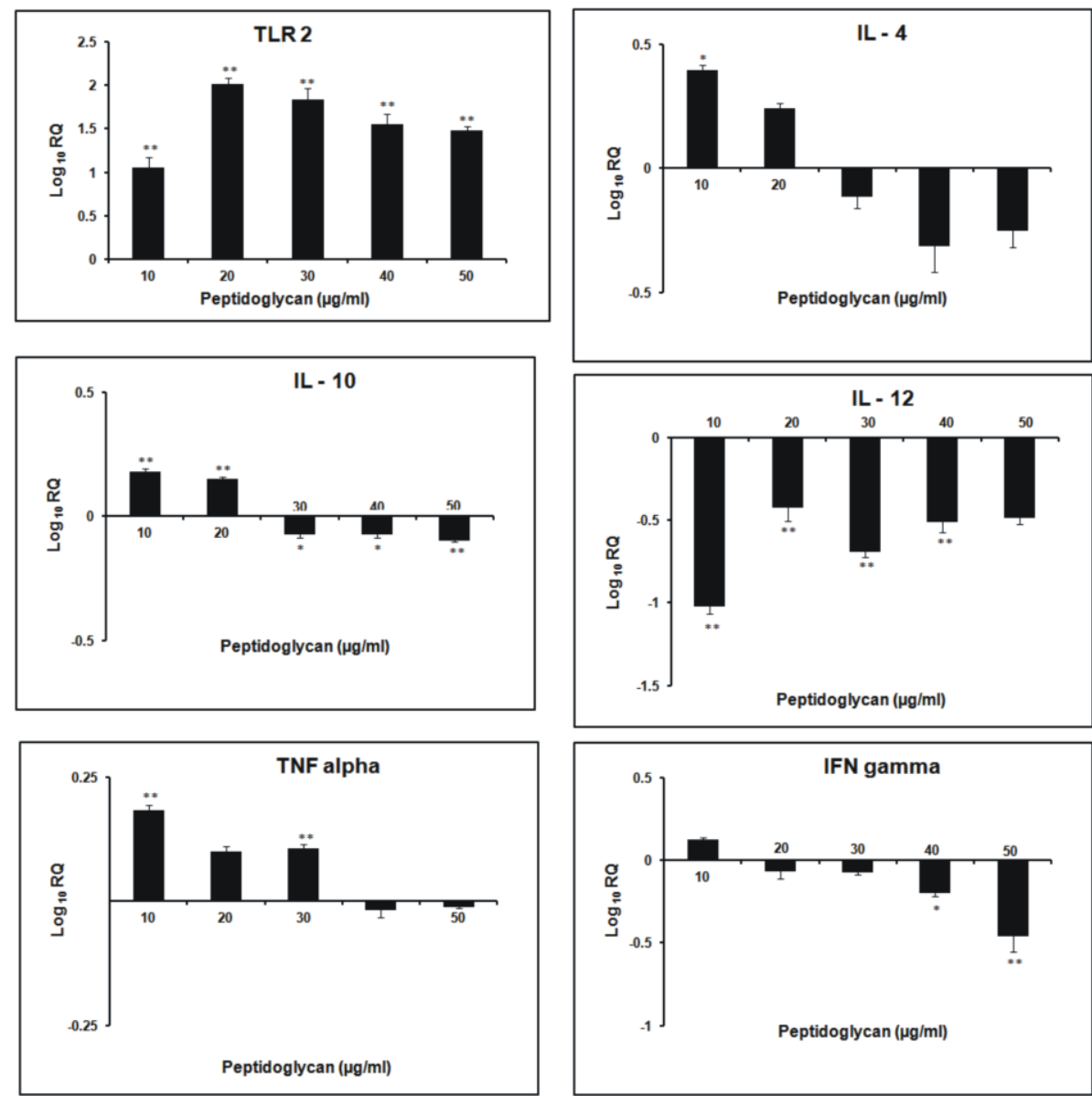

Figure 4. qPCR of TLR2, IL-12, TNF- $\alpha$, IFN- $\gamma$, IL-10 and IL-4 genes after stimulation with $B$. subtilis peptidoglycan for $36 \mathrm{~h}$. Results shown as fold change $\left(\log _{10}\right.$ relative quantification (RQ)) relative to the control group. The data are the means and SEM. * p<0.05 and $* * \mathrm{p}<0.01$.

Coffman, 1989). Thus, it might be concluded that moderate doses of antigen favoured Th2 type bias whereas higher doses of antigen favoured Th1 type cytokine pattern, almost in accordance to the observations made by Parish (1972) who concluded that both low and high amounts of antigen, in vitro, primed for Th1 type whereas moderate levels stimulated Th2 type cytokine release (Parish, 1972). At $24 \mathrm{~h}$ incubation period, the peptidoglycan induced tolerance at $30 \mu \mathrm{g} / \mathrm{ml}$ dose was not observed. This may be due to relatively more expression of TNF- $\alpha$ at $40 \mu \mathrm{g} / \mathrm{ml}$ dose, an up regulator of TLR2 (Zarember and Godowski, 2002), at this incubation. The expression pattern of IL-12 was almost similar to that of TLR2 showing that TLR2 signaling cascades have a direct impact on governing cytokine profile in response to an antigen in a dose- and time- dependent manner. The highest expression of IL-4 and IL-10 at 10 $\mu \mathrm{g} / \mathrm{ml}$ dose of sPGN may be due to a lower requirement of antigen dose for naïve T cells to secrete IL-4 (Eisenbarth et al., 2002). But for greater incubation periods and at higher antigen doses the naïve $\mathrm{T}$ cells shifted towards IL-12 producing subset, thereby governing the Th1 type response (Re and Strominger, 2001). An overall similar cytokine induction pattern, obtained at 12 and $24 \mathrm{~h}$ incubations might be suggestive of the optimum physiological response to the antigen. The cells became refractory to the peptidoglycan stimulation at longer incubation times, indicated by the decreased expression profile of all the cytokines at $36 \mathrm{~h}$ incubation, under the study. The overall decrease in expression of all the cytokines might also be due to cellular apoptosis induced by TLR2 (Aliprantis et al., 2000). The initial polarization towards Th2 type from the earlier Th1 type response indicated the effect of the dose and duration of exposure to an antigen on Th1/Th2 bias. This switching of immune response from Th2 type $(3 \mathrm{~h})$ to Th1 type (12 and $24 \mathrm{~h}$ ) and again to Th2 type ( $36 \mathrm{~h}$ ) may be due to wide range of antigen concentrations used in the studies ( 0 to 50

Table 2. Average cytokine inductions at different incubation intervals

\begin{tabular}{ll}
\hline Incubation time (h) & Cytokine levels \\
\hline 3 & IL-4>IL-10>TNF- $\alpha>$ IL-12 $>$ IFN- $\gamma$ \\
12 & IL-12>IFN- $\gamma>$ TNF- $\alpha>$ IL-10 $>$ IL-4 \\
24 & IL-12>IFN- $\gamma>$ TNF- $\alpha>$ IL-10 $>$ IL-4 \\
36 & TNF- $\alpha>$ IL-10 $>$ IL-4 $>$ IFN- $\gamma>$ L-12 \\
\hline
\end{tabular}


$\mu \mathrm{g} / \mathrm{ml}$ ) and the wide duration (3 to $36 \mathrm{~h}$ ) of exposure of the cultures to the antigen. This observation is in accordance with the two antigenic switches, Th1 to Th2 to Th1, as reported by Hosken et al. (1995).

\section{CONCLUSION}

The study gives an indication that the induction of a distinct Th phenotype is not dependent on a particular DC lineage but instead, depends on the state of activation and maturation of the DC and the TLR2 agonists could be used as effective vaccine adjuvants to direct the immune response towards Th1 type which is a key consideration in development of modern vaccines.

\section{REFERENCES}

Abbas, A. K., K. M. Murphy and A. Sher. 1996. Functional diversity of helper T lymphocytes. Nature 383:787-793.

Akira, S. and S. Sato. 2003. Toll-like receptors and their signaling mechanisms. Scand J. Infect. Dis. 35:555-562.

Aliprantis, A. O., R. B. Yang, D. S. Weiss, P. Godowski and A. Zychlinsky. 2000. The apoptotic signaling pathway activated by Toll-like receptor-2. EMBO J. 19:3325-3336.

D'Andrea, A., M. Aste-Amezaga, N. M. Valiante, X. Ma, M. Kubin and G. Trinchieri. 1993. Interleukin 10 (IL-10) inhibit human lymphocyte interferon gamma-production by suppressing natural killer cell stimulatory factor/IL-12 synthesis in accessory cells. J. Exp. Med. 178:1041-1048.

Dziarski, R. and D. Gupta. 2005. Staphylococcus aureus peptidoglycan is a toll-like receptor 2 activator: a reevaluation. Infect. Immun. 73:5212-5216.

Eisenbarth, S. C., D. A. Piggott, J. W. Huleatt, I. Visintin, C. A. Herrick and K. Bottomly. 2002. Lipopolysaccharide-enhanced, toll-like receptor 4-dependent $\mathrm{T}$ helper cell type 2 responses to inhaled antigen. J. Exp. Med. 196:1645-1651.

Gay, N. J. and F. J. Keith. 1991. Drosophila Toll and IL-1 receptor. Nature 351:355-356.

Hirschfeld, M., J. J. Weis, V. Toshchakov, C. A. Salkowski, M. J. Cody, D. C. Ward, N. Qureshi, S. M. Michalek and S. N. Vogel. 2001. Signaling by toll-like receptor 2 and 4 agonists results in differential gene expression in murine macrophages. Infect. Immun. 69:1477-1482.

Hosken, N. A., K. Shibuya, A. W. Heath, K. M. Murphy and A. O'Garra. 1995. The effect of antigen dose on CD4+ T helper cell phenotype development in a $\mathrm{T}$ cell receptor-alpha betatransgenic model. J. Exp. Med. 182:1579-1584.
Medzhitov, R. 2001. Toll-like receptors and innate immunity. Nat. Rev. Immunol. 1:135-145.

Mosmann, T. R. and R. L. Coffman. 1989. TH1 and TH2 cells: different patterns of lymphokine secretion lead to different functional properties. Annu. Rev. Immunol. 7:145-173.

Nakayama, K., S. Okugawa, S. Yanagimoto, T. Kitazawa, K. Tsukada, M. Kawada, S. Kimura, K. Hirai, Y. Takagaki and Y. Ota. 2004. Involvement of IRAK-M in peptidoglycan-induced tolerance in macrophages. J. Biol. Chem. 279:6629-6634.

Parish, C. R. 1972. The relationship between humoral and cellmediated immunity. Transplant. Rev. 13:35-66.

Perez, V. L., J. A. Lederer, A. H. Lichtman and A. K. Abbas. 1995. Stability of Th1 and Th2 populations. Int. Immunol. 7:869-875.

Re, F. and J. L. Strominger. 2001. Toll-like receptor 2 (TLR2) and TLR4 differentially activate human dendritic cells. J. Biol. Chem. 276:37692-37699.

Schmittgen, T. D. and K. J. Livak. 2008. Analyzing real-time PCR data by the comparative C(T) method. Nat. Protoc. 3:11011108.

Shah, S. M., R. Kumar and G. S. Brah. 2010. Identification and sequence analysis of TLR2 gene in Murrah buffalo. Online J. Vet. Res. 14:9.

Spellberg, B. and J. E. Edwards, Jr. 2001. Type 1/Type 2 immunity in infectious diseases. Clin. Infect. Dis. 32:76-102. $10.1086 / 317537$

Thanislass, J., G. Yuvaraj and K. V. Subba Reddy. 2009. Characterization of TLR4 signaling in water buffalo (Bubalus bubalis). Vet. Res. Commun. 33:97-102.

Tizard, I. R. 1996. Veterinary immunology, An introduction. 5th edn. W.B Saunders Company, New Delhi, India.

Travassos, L. H., S. E. Girardin, D. J. Philpott, D. Blanot, M. A. Nahori, C. Werts and I. G. Boneca. 2004. Toll-like receptor 2dependent bacterial sensing does not occur via peptidoglycan recognition. EMBO Rep. 5:1000-1006.

Wang, D., S. D. Westerheide, J. L. Hanson and A. S. Baldwin, Jr. 2000. Tumor necrosis factor alpha-induced phosphorylation of RelA/p65 on Ser529 is controlled by casein kinase II. J. Biol. Chem. 275:32592-32597.

Wang, J. E., P. F. Jorgensen, E. A. Ellingsen, M. Almiof, C. Thiemermann, S. J. Foster, A. O. Aasen and R. Solberg. 2001. Peptidoglycan primes for LPS-induced release of proinflammatory cytokines in whole human blood. Shock 16:178-182.

Zarember, K. A. and P. J. Godowski. 2002 Tissue expression of human Toll-like receptors and differential regulation of Tolllike receptor mRNAs in leukocytes in response to microbes, their products, and cytokines. J. Immunol. 168:554-561. 